\title{
Pasture Stocking Density and the Relationship to Animal Performance ${ }^{1}$
}

\section{Matt Hersom ${ }^{2}$}

The pasture/livestock production enterprise should be viewed as an integrated production system. An important step in improving the production efficiency of the system is to consider the interrelationship between the cattle and the pasture forage supply. Management of stocking density is one such relationship between grazing cattle and pastures. The stocking density of Florida pastures can impact beef cattle production, forage production, and enterprise profitability. The overall goal of managing grazing animals is to utilize the forage that a pasture already produces to its optimum potential.

\section{Cattle Forage Interaction}

There are many factors that affect a cattle producer's ability to properly stock pastures in Florida. These influential factors include agronomic, animal, and management considerations. Table 1 lists some of the factors that contribute to stocking density considerations. Many of these factors are interrelated with one another, and thus decisions made about one factor can have extensive effects on multiple related factors. However, the ultimate goal of any forage management system is to provide the required nutrients to grazing animals using pasture forage.
Some well defined relationships have been established concerning stocking density, individual animal performance, and gain per unit of land area. Figure 1 portrays the relationships between the grazing pressure on the pasture exerted by nominal stocking density and the responses of animal performance. Unfortunately, exact numbers in the figure can not be indicated because of the many interrelated factors concerning stocking density.

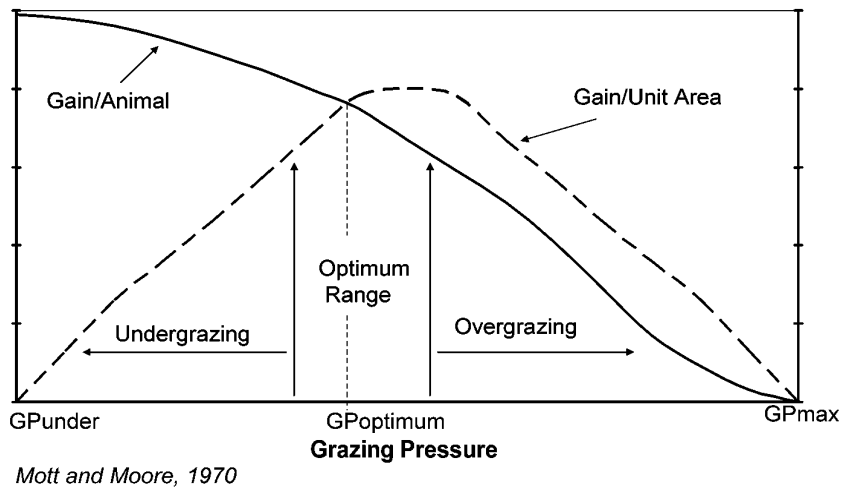

Figure 1. The relationship of grazing pressure and animal performance.

1. This document is AN155, one of a series of the Animal Science Department, Florida Cooperative Extension Service, Institute of Food and Agricultural Sciences, University of Florida. Original publication date August, 2005. Visit the EDIS Web Site at http://edis.ifas.ufl.edu.

2. Matt Hersom, Assistant Professor, Department of Animal Sciences, University of Florida, Institute of Food and Agricultural Sciences, Cooperative Extension Service, Gainesville, 32611.

The Institute of Food and Agricultural Sciences (IFAS) is an Equal Opportunity Institution authorized to provide research, educational information and other services only to individuals and institutions that function with non-discrimination with respect to race, creed, color, religion, age, disability, sex, sexual orientation, marital status, national origin, political opinions or affiliations. U.S. Department of Agriculture, Cooperative Extension Service, University of Florida, IFAS, Florida A. \& M. University Cooperative Extension Program, and Boards of County Commissioners Cooperating. Larry Arrington, Dean 
Table 1. Pasture stocking considerations.

\begin{tabular}{lll}
\hline Agronomic & Animal & Management \\
\cline { 2 - 3 } Forage species & Herd size & Supplementation amount \\
Fertilization application & Bodyweight & Supplementation type \\
Precipitation & Dry matter intake & Pasture management \\
Pasture size & Nutrient requirements & Forage allowance \\
Season & & Future forage needs \\
Forage seasonal growth & & \\
Forage chemical composition & & \\
Forage mass &
\end{tabular}

\section{Results of Stocking Density Research}

There is limited data in Florida that has addressed the effect of stocking density on cow-calf performance. General stocking density recommendations for Florida pastures include: bahiagrass, 1.5-4 ac/cow; bermudagrass, stargrass, and limpograss, 1-3 ac/cow; native range 5-25 ac/cow. Research from one experiment summarized in Table 2 demonstrates the effect of different stocking densities on cow and calf performance. Pastures that are more densely stocked during the winter do not support cow performance as well as pastures stocked at a lower density. However, because of pasture growth during the summer, stocking density did not affect overall cow performance. Calf performance also was not affected by stocking density. In contrast, calf production (total pounds of calf produced per acre) was greater on high stocking density pastures because more pounds of calf were produced on less land area. Because of the ability to produce more pounds of calf on a given land area there was nearly a one to one relationship between stocking density and ranch revenue. A decrease in stocking density of $10 \%$ resulted in a decrease in ranch revenue by $10 \%$ because there were fewer cows with which to assign the fixed costs associated with the land as stocking density decreased. It should be noted that these were not aggressively stocked pastures, and, as shown in Figure 1, there is a maximum profitable stocking density for every pasture.
Yearly fluctuations can influence the effect of stocking density on animal performance. While there is an optimal stocking density for each pasture, this stocking density will vary from year to year and likely from month to month. Figure 2 shows an example of the variation across four years in low and high stocking density pastures for grazing season length and carrying capacity. In years three and four, high stocking density decreased the grazing season length by 20 and 10 days respectively. In contrast, the high stocking density did significantly increase the carrying capacity of the pastures, thus providing more steer grazing days per acre of pasture.

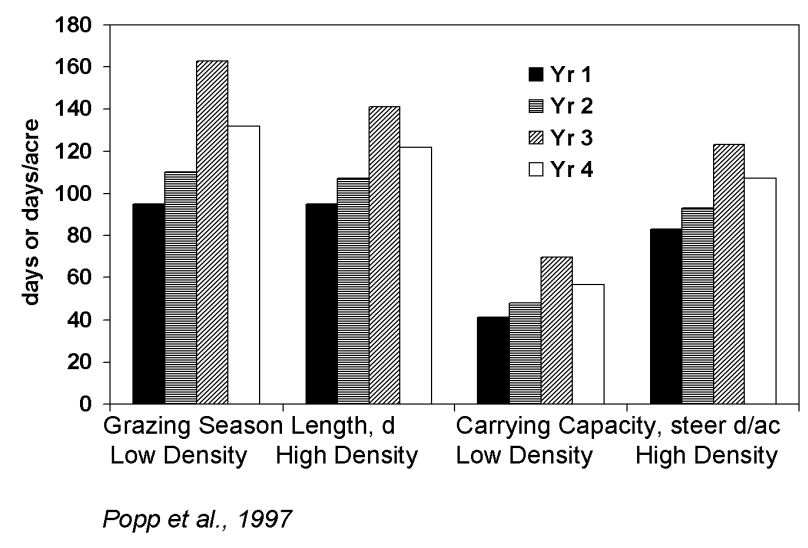

Figure 2. Effect of stocking density on pasture productivity.

Figure 3 is an example of the variation in animal performance across years between low and high stocking densities. Individual steer live bodyweight gain was greater for low stocking density pastures compared with highly stocked pastures in all years. This occurred because individual animals in lowly stocked pastures are generally allowed to gain to their genetic potential or the potential limited by forage quality. In contrast, high stocking density pastures 
Table 2. Effect of pasture stocking density on cow-calf performance in south Florida.

\begin{tabular}{lccc}
\hline & \multicolumn{3}{c}{ Stocking density } \\
\cline { 2 - 4 } Item & Low & $\begin{array}{c}\text { Medium } \\
(8.6 \mathrm{ac} / \text { cow })\end{array}$ & $\begin{array}{c}\text { High } \\
(3.7 \mathrm{ac} / \mathrm{ac} / \mathrm{cow})\end{array}$ \\
\cline { 2 - 4 } Winter BCS ${ }^{\mathrm{a}}$ & 5.0 & 5.0 & 5.0 \\
Summer BCS & $5.0^{\mathrm{b}}$ & $4.2^{\mathrm{d}}$ & $4.0^{\mathrm{d}}$ \\
Weaning BCS & 5.6 & 6.0 & 5.9 \\
Winter BCS change & $0.0^{\mathrm{c}}$ & $-0.85^{\mathrm{d}}$ & $-1.0^{\mathrm{d}}$ \\
Summer BCS change & 0.6 & 1.8 & 1.85 \\
Calf BW & Ib & 374 & 351 \\
Weaning BW, lb & 376 & 522 & 527 \\
ADG, Ib/d & 544 & 1.74 & 2.03 \\
Calf Production, Ib/ac & 1.95 & $77.4^{\mathrm{d}}$ & $136.5^{\mathrm{e}}$ \\
\hline
\end{tabular}

${ }^{a}$ BCS $=$ Body condition score

${ }^{\mathrm{b}} \mathrm{BW}=$ Body weight

${ }^{c, d, e}$ Means within a row with different superscripts differ $\mathrm{P}<0.05$.

Arthington et al., 2004

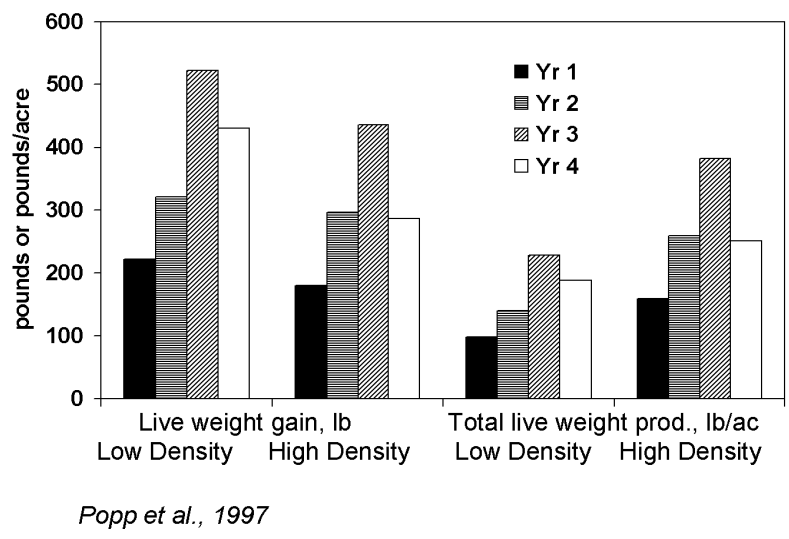

Figure 3. Effect of stocking density on beef steer production.

resulted in greater total live bodyweight production (pounds/acre) than lowly stocked pastures. Highly stocked pastures limit individual animal gains, but result in greater total body weight gain per unit of land area. Bodyweight gains of animals on highly stocked pastures are generally limited by forage availability rather than genetic potential.

Data from work conducted by IFAS demonstrate the effect of forage mass, forage allowance, and the corresponding stocking density. Research conducted by Newman et al. (2002) examined the interaction of limpograss and stocking density (Table 3 ). This work indicated an optimal forage mass to optimize heifer performance. Optimal forage mass balances the forage yield and forage quality to provide a forage source for grazing cattle. Forage allowance (pounds of forage mass / pounds of animal per acre) also has an optimum range as it relates to stocking density. If forage allowance is too low, animal intake can be limited and animal performance may then be sacrificed. A forage allowance that is too great may also limit animal performance in that forage quality may decline with additional herbage mass.

Additionally, too great a forage allowance wastes available forage through trampling and fouling of the forage.

\section{Issues Affecting Desired Stocking Density}

\section{Animal Requirements}

Often stocking density for a pasture or ranch as a whole is determined by history, or what has always been done. However, the number of animals a given piece of land can handle evolves as the genetic makeup and potential of the cow herd evolves. The average cow might have weighed 800 to 1,000 pounds 30 to 15 years ago. Recently, cow body weights have increased to nearly 1,200 pounds. If the herd's pasture area has not changed during that time, the stocking density has nearly doubled. Dry matter intake is linked to bodyweight, thus greater bodyweight equals increased forage intake. Without a change in land area or forage growth a decrease in forage allowance occurs, and a de facto increase in stocking density even though cow numbers and land area have not changed. 
Table 3. Effect of stocking density of limpograss pastures on heifer performance.

\begin{tabular}{ccccc}
\hline $\begin{array}{c}\text { Stocking density, } \\
\text { heifers/acre }\end{array}$ & $\begin{array}{c}\text { Canopy ht, } \\
\text { inches }\end{array}$ & $\begin{array}{c}\text { Forage mass, } \\
\text { lb/ac }\end{array}$ & $\begin{array}{c}\text { Forage allowance, } \\
\text { lb DM/lb BW }\end{array}$ & $\begin{array}{c}\text { Gain, } \\
\text { lb/ac }\end{array}$ \\
\hline 3.4 & 7.9 & 2,706 & 2.79 & 314 \\
2.5 & 15.7 & 4,117 & 5.17 & 302 \\
2.3 & 23.6 & 5,287 & 7.01 & 144 \\
\hline
\end{tabular}

Newman et al., 2002

\section{Forage Species}

Differences exist among forage species for growth pattern, forage yield, grazing tolerance, and forage quality. Each of these factors enters into the stocking density decision making process.

Additionally, many pastures are not monocultures of a forage species, thus complicating the decision making process. One should refer to the appropriate IFAS recommendations for planting, fertilization, and management of forage and pasture species.

\section{Soil Fertility}

Soil fertility can have a profound effect upon forage growth, yield, quality, and ultimately stocking density. An optimal soil fertility level exists for every grazing and stocking situation. Maximal soil fertility and subsequent forage growth may be wasted if the forage can not be utilized through grazing, conserving the forage as hay or balage, or some combination.

Likewise, deficient soil fertility makes inadequate use of the grazable land area for forage production and grazing.

\section{Environment}

Initiation of the grazing season and subsequent forage growth will be affected by ambient temperature and accumulated degree days. The amount and timeliness of precipitation during the growing season will affect forage yield and quality. Additionally, seasonal differences affect forage growth patterns that will result in stocking density differences.

\section{Stocking Density Generalizations}

In grazing management systems, a producer must determine what is his or her individual goal is. Generally, the goal is to utilize forage in a manner that maintains forage quality, and quantity for current and future grazing use. Low stocking density scenarios generally maximize individual animal performance because the cattle have the opportunity to selectively graze the pasture and thus production per unit of land area is sacrificed. Increasing stocking density generally will decrease individual animal performance but increase the production per unit of land area up to a given point (see Figure 1). Overall forage quality may be increased in heavily stocked pastures because the forage is being maintained in a vegetative state, but total quantity is depressed. Stocking density decisions may be a direct reflection on the assumption of the level of risk and/or level of management involved.

\section{Literature Cited}

Arthington, J., P. Bohlen, and F. Roka. 2004. Effect of stocking rate on measures of cow-calf productivity and nutrient loads in surface water runoff. 2004 FL. Ruminant Nutr. Symp. Gainesville, Florida.

Mott, G. O., and J. E. Moore. 1970. Forage evaluation techniques in perspective. In Proc. Natl. Conf. Forage Qual. Eval. and Util. Lincoln, Nebraska Center of Continuing Education, L1-10.

Newman, Y., C., L. E. Sollenberger, W. E. Kunkle, and C. G. Chambliss. 2002. Canopy height and nitrogen supplementation effects on performance of heifers grazing limpograss. Agron. J. 94:1375-1380.

Popp, J. D., W. P. McCaughey, and R. D. H. Cohen. 1997. Grazing system and stocking rate effects on the productivity, botanical composition and soil surface characteristics of alfalfa-grass pastures. Can. J. Anim. Sci. 77:669-676. 